\title{
Gender and Community Mainstreaming in Fog Water Collection Systems
}

\author{
Kayla J. Lucier ${ }^{1}$ and Manzoor Qadir ${ }^{2, *}$ (C) \\ 1 Department of Health Research Methods, Evidence, and Impact, McMaster University, \\ Hamilton, ON L8S 4L8, Canada; lucierkj@mcmaster.ca \\ 2 United Nations University Institute for Water, Environment and Health (UNU-INWEH), \\ Hamilton, ON L8P 0A1, Canada \\ * Correspondence: Manzoor.Qadir@unu.edu; Tel.: +1-905-667-5511
}

Received: 17 August 2018; Accepted: 11 October 2018; Published: 19 October 2018

\begin{abstract}
Fog water collection is an emerging opportunity to combat local water shortages in water-scarce areas where sustainable access to water is unreliable, but fog events are frequent. Since fog water systems are implemented within or near communities, they eliminate or decrease the need to travel far distances for the collection of water during times of scarcity. As a result, these systems decrease the physical and social burden of water collection on women and girls, who are the primary water gatherers in most traditional communities. This is an important outcome because women and girls are disproportionately affected by water scarcity and are not seen as equals in water management, access, or control. This paper illustrates how several fog water collection projects have shown, empirically, that the positive outcomes for women and girls may include the freeing of time for domestic and educational pursuits, improved health outcomes, and improved perceptions of self and others' perceptions of women. These findings are important at a time when the world at large is addressing the Sustainable Development Agenda, where Sustainable Development Goal (SDG) 6 necessitates safe water and sanitation for all and SDG 5 ensures gender equality to empower all women and girls.
\end{abstract}

Keywords: water scarcity; water insecurity; unconventional water resources; fog; atmospheric water; gender mainstreaming; sustainable development

\section{Introduction}

Water insecurity occurs when a population, for many complex and multifaceted reasons, is incapable of ensuring sustainable access to adequate quantities of safe, quality water [1]. Water scarcity, a form of water insecurity, is increasingly driven by climate change coupled with a rising demand for water by a growing population [2]. It may also result from the social and political landscape of a region, where water is diverted from rural to urban or industrial zones to meet the needs of developing nations [3]. In addition, some countries or areas are water-scarce due to an uneven distribution of water resources and population densities [4,5]. Worldwide, projections predict a surge in the number of people living in severely water-scarce regions, increasing from approximately 1.9 billion people around 2015 to approximately 3.2 billion by 2050 [2].

Conventional approaches relying on rainfall and river runoff in water-scarce areas are not sufficient to meet the human need for water. Water-scarce countries and communities need a new water paradigm considering a range of unconventional water resources to narrow the water demand-supply gap [6]. Such water resources are critically important to address local water shortages $[7,8]$. One such resource is water embedded in fog, which is particularly valuable in dry areas where fog events are common. 
Fog water collection systems have been implemented in countries in South and Central America, the Caribbean, Africa, and Southern Europe $[9,10]$. Parts of these countries receive little rainfall annually and may go through periods where rainfall is non-existent, making surface- and/or groundwater collection exceptionally difficult $[9,11]$. However, the arid or semi-arid tropical or sub-tropical climates in certain dry areas, coupled with cool air from nearby oceans, produce the conditions necessary for consistent fog accumulation at high elevations [11]. Fog water collection projects have shown that fog events in these areas tend to occur more frequently than rainfall events and may provide a more reliable, consistent source of water than conventional sources [12].

Fog masses are composed of droplets of water suspended in the air, like a cloud. Fog water collection is achieved by placing a large sheet of mesh, made of various materials, facing the prevailing wind direction. As the wind blows a fog mass against the mesh, small fog droplets combine into water droplets large enough to run down the mesh into a water collection channel. From there, water flows into a storage tank that local community members can access and draw from when needed [9-11]. Post-installation, fog water collection systems require little physical and monetary upkeep, making them an attractive, though unusual, water source [7].

Collecting atmospheric moisture is far from a new intervention, as one of the earliest evidences aimed at determining the volume of fog deposition was undertaken from 1901-1904 in South Africa, to investigate the feasibility and productivity of fog as a natural supplement to otherwise limited water resources [13]. Later efforts focused on the material composition of fog collection nets and their sizes; a timeline on the history of several fog water collection methods practiced in arid and semi-arid areas is available elsewhere [11].

The most commonly used fog water collection systems are based on Standard Fog Collectors (SFC) and Large Fog Collectors (LFC), which are available in the market [14]. One unit of the SFC has an area of $1 \mathrm{~m} \times 1 \mathrm{~m}\left(1 \mathrm{~m}^{2}\right)$, while the size of LFC varies from $40 \mathrm{~m}^{2}(4 \mathrm{~m} \times 10 \mathrm{~m})$ to $48 \mathrm{~m}^{2}(4 \mathrm{~m} \times 12 \mathrm{~m})$ per unit. The number, size, and type of fog collectors to be installed in a specific location depends on the fog characteristics, such as fog thickness, duration and frequency of occurrence, as well as the climate and topography of the area, water demand, and financial and human capacity of the associated community to run and maintain the fog collection system [7]. Fog days range from 60 to 360 days on fog collection sites, while daily fog water yield varies from 2 to $20 \mathrm{~L} \mathrm{~m}^{-2}$ of fog water collection unit.

Extensive reviews are available on the history, characteristics, and technical features of fog water collection [14-16] as well as on policy and institutional aspects, economic and financial dimensions, and capacity-building activities [7,9]. However, information on trade-offs of community and gender aspects of fog water collection is scattered and fragmented, warranting a review to combine existing knowledge of community and gender aspects of fog water projects across the globe. Such a review is important at a time when the global community is addressing the Sustainable Development Goals (SDGs), where SDG 6 necessitates safe water and sanitation for all and SDG 5 ensures gender equality, with a focus on the empowerment of women and girls. To date, there is no review article published exclusively on community and gender aspects of fog water collection systems. The purpose of this paper is to review, for the first time, how fog water collection systems impact women and community, based on empirical evidence.

\section{Methodology}

In the literature search process, academic publications addressing fog water harvesting were first identified using key literature databases, such as Google Scholar, Science Direct, and Scholars Portal Journals (a search engine service provided by the Ontario Council of University Libraries) as well as web-based search engines, scientific journals, and the proceedings of conferences and workshops. The articles included were written in English and published from 1981 onwards. These publications were more than 200 in number. The titles, abstracts, and contents of these publications were individually evaluated to confirm the relevance of those related to gender aspects of fog collection systems. 
Of all the publications addressing fog water collection, 15 were found to specifically address gender-related aspects of fog water collection and were referenced for this review. All literature on the fog water-gender nexus addressed trends only and included no quantitative data to quantify gender and/or community benefits after installation of fog water systems. However, these studies on fog collection systems showed positive outcomes for women, girls, and community, such as free time for domestic and educational purposes; better health; and positive feelings and position within the community. We synthesized this information and accompanying trends, which are presented in Section 3.

Beyond fog water collection systems, many water projects have quantified improved physical and social outcomes because of closer, more reliable, and better access to safer water sources. In Section 4, we present summaries of three projects undertaken in different parts of the world-Ghana, Nigeria, and India-to illustrate what may occur in water-scarce communities after fog water collection systems are installed from the perspective of non-fog related initiatives. The gender-related key findings of these projects were chosen due to their diverse implementation strategies but common outcomes of improving the lives of women and communities in a quantifiable manner.

\section{Water and Gender}

Water is not a "gender neutral" resource; women and girls are disproportionately affected by water scarcity, as they are the primary water gatherers and users in most traditional, non-urban communities worldwide [11,17-20]. Women and men are not seen as equals in water management, access, or control; water scarcity may widen this gap of inequity between the sexes, leaving women who may already be facing hardship at an even greater disadvantage [3,20]. Collecting water in arid climates, where water sources are few and far between, may take women and girls up to 4 or more hours per day and involve walking substantial distances, leaving them with little time to pursue other productive and meaningful activities [21,22].

Since fog water collection systems are implemented within or near communities, they eliminate or substantially decrease the need to travel far distances for water $[17,21]$. Thus, these systems decrease the physical and social burden of water collection on women and girls, in addition to the anticipated increase in water quality and quantity for the entire community. However, the question remains: If we remove the barrier of time and energy from water collection through fog water technologies, what are the physical and social benefits for women, girls, and the communities in which they live? This paper attempts to respond to this question, using evidence from fog water installations across the globe and by exploring the effects of similar water-related projects. Empirical evidence from fog water collection projects shows that the positive physical and social outcomes for women and girls may include: (1) A drastic decrease in the time previously spent on water collection from far distances, resulting in the freeing of time for domestic and educational pursuits in fog collection areas; an increase in school attendance by girls; and the establishment of female cooperatives to promote home-made products resulting in economic independence [11,21-25]; (2) improved health outcomes through immediate decrease in the use of contaminated water collected previously from polluted water sources and access to, and use of, better quality water collected from fog leading to a decrease in water-borne diseases and improvement in health and wellness [3,9,19,26-31]; and (3) improved perceptions of self and position within the community through self-confidence, gender equality, recognition of women's contribution and shared ownership of the female segment of the community in fog collection systems $[3,7,17,18,21]$. Figure 1 provides an overview of the outcomes of gender and community mainstreaming through fog water collection projects in areas where weather conditions are favorable for fog collection. 


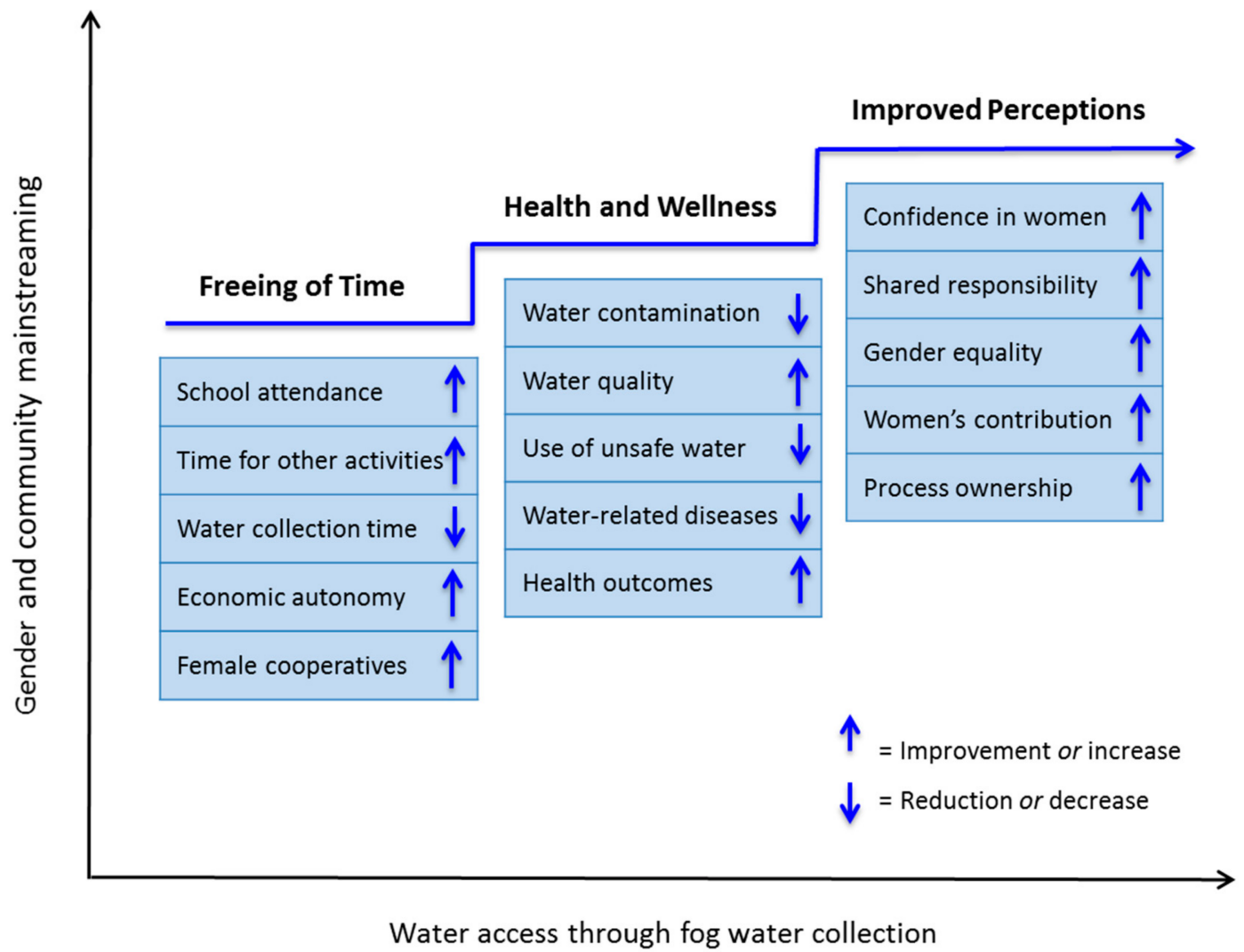

Figure 1. Key elements of gender and community mainstreaming through fog water collection projects showcasing a range of positive outcomes for the female segment of the communities moving from time-consuming and laborious water collection approaches to using fog water collection systems (Based on the empirical evidence and trends from fog water collection projects in different parts of the world in areas where weather conditions are favorable for fog collection).

\subsection{Freeing of Time for Productive Activites}

When the barrier of distance, and therefore time, is removed, as is the case with fog water collection systems, women and girls are left with more free time to pursue other activities. For girls, this means that they are more likely to attend school [21]. Additionally, a closer and more reliable water source may mean that girls stay in school longer, as a lack of water is one of the major barriers to attending school for menstruating girls $[23,24]$.

For women, researchers have noted that free time means that they are able to be more involved with domestic and agricultural initiatives that benefit their families, while also contributing to sustainable development and to conserving traditional activities [11,22]. These female-led domestic and agricultural activities may also result in economic autonomy for women and greater independence [25]. In addition, there is some evidence that improved water availability and increased free time supports the creation of women's cooperatives, providing an opportunity for women to connect in a productive and meaningful way [22].

\subsection{Improved Health Outcomes}

Fog water is a safer and healthier alternative to groundwater and well water. In water-scarce regions, surface water can become increasingly contaminated as the amount of water available for consumption decreases [3]. Estimates indicate that approximately one-quarter of people worldwide drink water contaminated with fecal indicator bacteria and that this contamination is more likely in groundwater or in rural piped sources [26]. Additionally, just over 500,000 diarrheal deaths can be linked to inadequate drinking water in low- and middle-income countries [26]. Overall, in 2016, 
unsafe drinking water, sanitation, and hygiene (WaSH) practices caused an estimated 870,000 deaths, with the mortality rate attributed to poor WaSH as high as 101 deaths per 100,000 people [27].

Results from the chemical analyses of fog water show consistently that heavy metals and minerals, if present, usually fall within the guidelines outlined by the World Health Organization drinking water quality standards $[9,28,29]$. Fog water has the potential to become contaminated in areas with significant industrial activity or where airborne pollution is high; however, most communities that rely on fog water as their main water source are rural and would not be expected to face these issues [29]. The literature bears no mention of microbial contaminants in fog water, which would, plausibly, only be introduced through poor collection and storage techniques and not through the water collection system itself.

Research has shown that there is a direct correlation between women's hours spent collecting water during times of water scarcity and poor health outcomes [30]. As women may be forced to collect lower quality water when it is not in abundance, they tend to bear the burden of water-borne diseases. Additionally, men are given a priority over women when it comes to their water needs, so women may be more likely to suffer the consequences of contaminated water or lack of water [30]. Physical health is also an important consideration-women collecting water from distant sources usually do not have the proper clothing or footwear for this kind of activity [19]. Evidence also suggests that head, neck, and back pain and fatigue can occur as a result of repeated water collection and transport [31]. Women and girls carrying water may also have to navigate slippery conditions and physical obstacles which could lead to falls and injury [31]. Since fog water systems eliminate the need to both travel for water and use unsafe water sources, women's health outcomes are expected to improve with system implementation.

\subsection{Better Perceptions of Self and Involvement in Community}

Though the physical benefits of fog water collection may be more apparent than the social or personal benefits for women and girls, these are no less important or valuable. In communities where fog water systems are introduced, there are often clear gender roles and responsibilities that differ between women and men. In patriarchal communities, men may not be confident about women's capacity to perform administrative tasks related to fog collection systems [17]. Women, too, may have little self-assurance about their involvement because they have never been given the opportunity to explore their abilities. However, as primary water gatherers and users, women are acutely attuned to predictors of change in climate and rainfall and have a heightened understanding of local water knowledge and resources, making their involvement indispensable [17,18].

In fog water projects where women are involved from the start, men may be more keen to recognize the importance of women and of the traditional tasks they accomplish day-to-day that are related to water collection [7]. Subsequently, over time, women who are involved and recognized may develop confidence in their abilities and assume fog water system activities beyond collection, such as filling in custodial, technical, managerial, or decision-making roles [21]. As these tasks are traditionally saved for men, fog water projects may foster equity among the sexes and challenge traditional gender roles [3].

\section{Precedent from Other Water Projects}

Although empirical evidence and trends from fog water collection projects show positive physical and social outcomes for women and girls, no studies or projects around fog water collection systems have been undertaken to quantify gender and/or community benefits after fog water system installation. However, many water projects quantify improved physical and social outcomes because of closer, more reliable, and safer water sources. We present summaries of three water projects implemented in Ghana, Nigeria and India to illustrate the benefits for women, girls and community at large in a quantifiable manner. 
In Ghana, women and children are the primary collectors and users of household water; as such, they are the most affected segment of their communities when water systems breakdown. A project addressing gender integration in a rural water management system was implemented in a community of 650 inhabitants with farming as a major source of livelihoods in Samari-Nkwanta area, about $373 \mathrm{~km}$ from Accra. Before the water project, women in this area used to work for about $19 \mathrm{~h} \mathrm{~d}^{-1}$, while men worked around $12 \mathrm{~h} \mathrm{~d}^{-1}$. To facilitate access to water, two boreholes fitted with hand pumps were drilled, as the nearest water source was a significant distance away. After boreholes were introduced, women gained approximately 5 extra productive hours per day, girls' enrollment in school increased by $10 \%$, and guinea worm was eradicated in all persons using the improved water sources [32].

In Nigeria, the Obudu plateau is one of the country's two mountain ecosystems and is home to tropical forests and large pastures. The top of the plateau is also used by the local agricultural and pastoralist communities. It was noted that women in Obudu plateau were complaining about poor family health, wasted time in collecting water, and poor quality of the collected water. To mainstream gender concerns, the Nigerian Conservation Foundation implemented a project by using participatory approaches to ensure women's involvement throughout the project cycle by including them at every stage—design, implementation, and monitoring—of the project. Based on a watershed and watercourse mapping survey, the project built two water reservoirs to improve water access for the community confronted with an unreliable supply of water, which was not close by. After reservoir construction, women and girls had considerably more time to devote to farming, vending and education. Diarrhea in women also decreased by $45 \%$ and men in the community were more open to the needs of women and to valuing their participation in water-related projects [32].

In Rajasthan state in India, a water management project addressed the key issue of the common failure of male mechanics to respond quickly to broken hand-pumps, which were mainly used by women for domestic purposes. The women in the area were first trained to fix broken hand pumps, followed by full responsibility for pump repairs. As women were interacting with these pumps more frequently, they were able to access the problem quickly and fix pumps immediately. Observations after water pump repair training and changes in the leadership role of women who were repairing pumps revealed that breakdowns occurred less often once female mechanics were introduced to the community. Additionally, the trained women were more effective in delivering public health messages related to water than their male counterparts [20].

\section{Conclusions}

Fog water collection systems, as an approach to dealing with water scarcity, have the potential to serve as an avenue for improving the lives of women and girls in low- and middle-income communities and countries. Fog water projects have shown that female community members may benefit from the freeing of time for other pursuits, as well as improved health outcomes and perceptions of self. There is also a precedent for positive, measurable outcomes from other water-related projects, which could be studied in more detail in a fog water collection context. Though it is unlikely that all fog water collection projects will have the same positive outcomes to the same degree, this review serves to highlight the range of possibilities for women, girls, and the community from fog collection systems.

Though some empirical evidence exists, there is a need for higher quality research that quantifies the benefits for women and girls after introduction of fog water collection systems. Future research should include a comprehensive assessment on fog water and gender- and community-related aspects. A community-based participatory research approach, which involves women throughout the research process, should also be considered given the social justice and action-oriented needs of this population.

Sustainable Development Goals (SDGs) 5 and 6 support the recommendation that future fog water collection system research focuses on gender outcomes. The key objective of SDG 5 is to achieve gender equality and female empowerment, while SDG 6 aims at ensuring availability and sustainable management of water and sanitation for all; a study that ties together both goals will be of importance not only to individual projects, but to all communities and countries considering fog water collection 
systems as viable options for combatting local water scarcity and improving gender equality through innovative water management $[33,34]$.

Author Contributions: This paper was jointly developed and written by both authors. The specific contributions were as follows: Conceptualization, M.Q. and K.J.L.; Literature Collection and Synthesis, K.J.L.; Methodology, M.Q. and K.J.L.; Initial Draft Preparation, K.J.L.; Figure, M.Q. and K.J.L.; Revised Versions and Final Draft, K.J.L. and M.Q.

Funding: This work is part of the UNU-INWEH's project on unconventional water resources. UNU-INWEH is supported by funding from the Government of Canada through Global Affairs Canada.

Conflicts of Interest: The authors declare no conflicts of interest.

\section{References}

1. Jepson, W.E.; Wutich, A.; Collins, S.M.; Boateng, G.O.; Young, S.L. Progress in household water insecurity metrics: A cross-disciplinary approach. Wiley Interdiscip. Rev. Water 2017, 4, e1214. [CrossRef]

2. Burek, P.; Satoh, Y.; Fischer, G.; Kahil, T.; Nava Jimenez, L.; Scherzer, A.; Tramberend, S.; Wada, Y.; Eisner, S.; Flörke, M.; et al. Water Futures and Solution: Fast Track Initiative Final Report. 2016. Available online: http:/ / pure.iiasa.ac.at/id/eprint/13008/1/WP-16-006.pdf (accessed on 12 June 2018).

3. World Water Assessment Programme. The United Nations World Water Development Report 4: Managing Water under Uncertainty and Risk; UNESCO: Paris, France, 2012; Available online: http:/ / unesdoc.unesco.org/ images/0021/002156/215644e.pdf (accessed on 21 June 2018).

4. Rijsberman, F.R. Water scarcity: Fact or fiction? Agric. Water Manag. 2006, 80, 5-22. [CrossRef]

5. Qadir, M.; Sharma, B.R.; Bruggeman, A.; Choukr-Allah, R.; Karajeh, F. Non-conventional water resources and opportunities for water augmentation to achieve food security in water scarce countries. Agric. Water Manag. 2007, 87, 2-22. [CrossRef]

6. World Bank. Beyond Scarcity: Water Security in the Middle East and North Africa; World Bank: Washington, DC, USA, 2017; ISBN 978-1-4648-1144-9.

7. Qadir, M.; Jiménez, G.C.; Farnum, R.L.; Dodson, L.L.; Smakhtin, V. Fog water collection: Challenges beyond technology. Water 2018, 10, 372. [CrossRef]

8. Abdul-Wahab, S.A.; Al-Damkhi, A.M.; Al-Hinai, H.; Al-Najar, K.A.; Al-Kalbani, M.S. Total fog and rainwater collection in the Dhofar region of the Sultanate of Oman during the monsoon season. Water Int. 2010, 35, 100-109. [CrossRef]

9. Klemm, O.; Schemenauer, R.S.; Lummerich, A.; Cereceda, P.; Marzol, V.; Corell, D.; Van Heerden, J.; Reinhard, D.; Gherezghiher, T.; Olivier, J.; et al. Fog as a fresh-water resource: Overview and perspectives. Ambio 2012, 41, 221-234. [CrossRef] [PubMed]

10. Batisha, A.F. Feasibility and sustainability of fog harvesting. Sustain. Water Qual. Ecol. 2015, 6, 1-10. [CrossRef]

11. Fessehaye, M.; Abdul-Wahab, S.A.; Savage, M.J.; Kohler, T.; Gherezghiher, T.; Hurni, H. Fog-water collection for community use. Renew. Sustain. Energy Rev. 2014, 29, 52-62. [CrossRef]

12. Ritter, A.; Regalado, C.M.; Guerra, J.C. Quantification of fog water collection in three locations of tenerife (Canary Islands). Water 2015, 7, 3306-3319. [CrossRef]

13. Olivier, J. Fog-water harvesting along the West Coast of South Africa: A feasibility study. Water SA 2002, 28, 349-360. [CrossRef]

14. Domen, J.K.; Stringfellow, W.T.; Camarillo, M.K.; Gulati, S. Fog water as an alternative and sustainable water resource. Clean Technol. Environ. Policy 2014, 16, 235-249. [CrossRef]

15. LeBoeuf, R.; de la Jara, E. Quantitative goals for large-scale fog collection projects as a sustainable freshwater resource in northern Chile. Water Int. 2014, 39, 431-450. [CrossRef]

16. Pérez-Díaz, J.; Ivanov, O.; Peshev, Z.; Álvarez-Valenzuela, M.; Valiente-Blanco, I.; Evgenieva, T.; Dreischuh, T.; Gueorguiev, O.; Todorov, P.; Vaseashta, A. Fogs: Physical Basis, Characteristic Properties, and Impacts on the Environment and Human Health. Water 2017, 9, 807. [CrossRef]

17. Dodson, L.L. A Foggy Desert: Equitable Information Flow for a Fogwater System in Southwest Morocco. Ph.D. Thesis, University of Colorado Boulder, Boulder, CO, USA, 2014.

18. UNDP and Republic of Yemen. Manakha Fog Harvesting Pilot Project, Sana'a Governorate; UNDP: New York, NY, USA, 2013. 
19. Schemenauer, R.S.; Rosato, M.; Carter, V. Fog collection projects in Tojquia and La Ventosa, Guatemala. In Proceedings of the 4th International Conference on Fog, Fog Collection and Dew, La Serena, Chile, 22-27 July 2007; pp. 22-27.

20. Sever, C. Gender and Water: Mainstreaming Gender Equality in Water, Hygiene and Sanitation Interventions; Swiss Agency for Development and Cooperation (SDC), Federal Departement of Foreign Affairs (DFA): Bern, Switzerland, 2005; Available online: https://static1.squarespace.com/static/ 536c4ee8e4b0b60bc6ca7c74/t/53c54145e4b0d5974bbf10c6/1405436229252/SDC+gender++water.pdf (accessed on 28 June 2018).

21. Dodson, L.L.; Bargach, J. Harvesting fresh water from fog in rural morocco: Research and impact Dar Si Hmad's Fogwater Project in Ait Baamrane. Procedia Eng. 2015, 107, 186-193. [CrossRef]

22. Marzol, M.V.; Megía, J.L.S. Fog Water Harvesting in Ifni, Morocco. An Assessment of Potential and Demand. Die Erde 2008, 139, 97-119.

23. Sommer, M.; Figueroa, C.; Kwauk, C.; Jones, M.; Fyles, N. Attention to menstrual hygiene management in schools: An analysis of education policy documents in low- and middle-income countries. Int. J. Educ. Dev. 2017, 57, 73-82. [CrossRef]

24. Jasper, C.; Le, T.-T.; Bartram, J. Water and Sanitation in Schools: A Systematic Review of the Health and Educational Outcomes. Int. J. Environ. Res. Public Health 2012, 9, 2772-2787. [CrossRef] [PubMed]

25. Bargach, J.; Dodson, L.; Farnum, R.L. Net Change: Harvesting Fog for Resilience in Southwest Morocco. In Proceedings of the International Conference: Water Energy \& Climate Change, WECC2016, Marrakech, Morocco, 1-4 June 2016.

26. Department of Public Health Environmental and Social Determinants of Health. Preventing Diarrhoea through Better Water, Sanitation, and Hygiene: Exposures and Impacts in Low-and Middle-Income Countries; World Health Organization: Geneva, Switzerland, 2014; Available online: http:/ / apps.who.int/iris/bitstream/handle/ 10665/150112/9789241564823_eng.pdf?sequence=1 (accessed on 21 June 2018).

27. World Health Organization. World Health Statistics 2018: Monitoring Health for the SDGs; World Health Organization: Geneva, Switzerland, 2018; Available online: http:/ / apps.who.int/iris/bitstream/handle/ 10665/272596/9789241565585-eng.pdf?ua=1 (accessed on 21 June 2018).

28. Gandhidasan, P.; Abualhamayel, H.I. Exploring Fog Water Harvesting Potential and Quality in the Asir Region, Kingdom of Saudi Arabia. Pure Appl. Geophys. 2012, 169, 1019-1036. [CrossRef]

29. Gandhidasan, P.; Abualhamayel, H.I. Fog collection as a source of fresh water supply in the Kingdom of Saudi Arabia. Water Environ. J. 2007, 21, 19-25. [CrossRef]

30. Buor, D. Water needs and women's health in the Kumasi metropolitan area, Ghana. Health Place 2004, 10, 85-103. [CrossRef]

31. Geere, J.-A.L.; Hunter, P.R.; Jagals, P. Domestic water carrying and its implications for health: A review and mixed methods pilot study in Limpopo Province, South Africa. Environ. Health 2010, 9, 52. [CrossRef] [PubMed]

32. UN Office of the Special Adviser on Gender Issues and Advancement of Women Department. Gender, Water and Sanitation: Case Studies on Best Practices; New York. 2006. Available online: http:/ /www.un. org/esa/sustdev/sdissues/water/casestudies_bestpractices.pdf (accessed on 28 June 2018).

33. United Nations Statistics Division. Goal 5 Achieve Gender Equality and Empower all Women and Girls. 2016. Available online: https://unstats.un.org/sdgs/files/metadata-compilation/Metadata-Goal-5.pdf (accessed on 20 July 2018).

34. United Nations Statistics Division. Goal 6 Ensure Availability and Sustainable Management of Water and Sanitation for All. 2016. Available online: https://unstats.un.org/sdgs/files/metadata-compilation/ Metadata-Goal-6.pdf (accessed on 20 July 2018).

(C) 2018 by the authors. Licensee MDPI, Basel, Switzerland. This article is an open access article distributed under the terms and conditions of the Creative Commons Attribution (CC BY) license (http://creativecommons.org/licenses/by/4.0/). 